\title{
Comparison of Glycosyltransferase Families Using the Profile Hidden Markov Model
}

\section{プロファイル隠れマルコフモデル法を用いた糖転移酵素ファミリーの比較}

\author{
Kikuchi, Norihiro ${ }^{* \dagger}$; Kwon, Yeon-Dae ${ }^{* \dagger}$; Gotoh, Masanori ${ }^{* \neq}$; and Narimatsu, Hisashi ${ }^{* q}$ \\ *Glycogene Function Team, Research Center for Glycoscience (RCG), National Institute of Advanced Industrial Science and \\ Technology (AIST), Open Space Laboratory C-2, 1-1-1 Umezono, Tsukuba, Ibaraki 305-8568, Japan \\ ${ }^{\dagger}$ Mitsui Knowledge Industry Co., Ltd., Honcho 1-Chome, Nakano-ku, Tokyo 164-8721, Japan \\ ${ }^{\ddagger}$ Amersham Biosciences KK, 3-25-1, Hyakunincho, Shinjuku-ku, Tokyo 169-0073, Japan \\ "Address correspondence and proofs to: Hisashi Narimatsu, MD \& PhD, Glycogene Function Team, \\ Research Center for Glycoscience (RCG), National Institute of Advanced Industrial Science and Technology (AIST), \\ Open Space Laboratory (OSL), C-2, 1-1-1 Umezono, Tsukuba, Ibaraki 305-8568, Japan \\ FAX: 81-29-861-3201, E-mail: h.narimatsu@aist.go.jp
}

Key Words: glycosyltransferase, glycosylation pathway, hidden markov model, subcellular localization

\begin{abstract}
In order to investigate the relationship between glycosyltransferase families and the motifs for them, we classified forty-seven glycosyltransferase families in the CAZy database into four superfamilies, GTS-A, -B, -C and -D, using a profile Hidden Markov Model method. On the basis of the classification and the similarity between GTS-A and nucleotidylyltransferase family catalyzing the synthesis of nucleotide-sugar, we proposed that ancient oligosaccharide might have been synthesized by the origin of GTS-B whereas the origin of GTS-A might be the gene encoding for synthesis of nucleotidesugar as the donor and which have evolved to glycosyltransferases to catalyze the synthesis of divergent carbohydrates. We also suggested that the divergent evolution of each superfamily in the corresponding subcellular component has increased the complexities of eukaryotic carbohydrate structure.
\end{abstract}

要 約

糖転移酵素ファミリー間の関係とそれらのモチーフについて 調べるため、我々はプロファイル HMM 法を用いCAZy デー夕 ベースの 47 糖転移酵素ファミリーを 4 つのスーパーファミリー (GTS-A、B、C、D) に分類した。その結果得られた分類および、 GTS-Aと糖ヌクレオチド合成を触媒する nucleotidylyltransferase ファミリーとの配列類似性から、我々は古代の糖鎖はGTS-B の 祖先型により合成され、GTS-A は基質である糖又クレオチドを 合成する遺伝子であったという仮説を提唱した。その後、GTSA の祖先型は糖転移酵素へと進化し、それに伴い糖鎖構造の多 様性が増していったと考えられる。また、スーパーファミリー はそれぞれ固有の細胞内局在部位で進化し、それにより糖鎖構 造の多様性が増していったということが示唆される。

A. はじめに

糖転移酵素は、糖鎖の開始・伸長の際、モノあるいはオリ ゴ糖を受容体分子に転移することにより、自然界で多種多様な 構造・機能を持つ carbohydrate や glycoconjugate の合成を触媒す る(1)。これら多種多様な糖転移酵素の立体構造や特異性、糖転 移反応機構についてはあまり知られていないが、糖転移酵素 データベースCAZyでは、BLASTによる配列類似性から糖転移 酵素が 60 のファミリー (GT-1〜60)へと分類されている (2)。 我々はプロファイル HMM 法を用いてこれらファミリー間に類 似した領域を同定し、それを基に糖転移酵素ファミリーを 4 種 類のスーパーファミミリーへと分類した (3)。 


\section{B. Identification of Four Superfamilies Using the Profile HMM Method}

Forty-seven of sixty families in CAZy were classified into four groups using the profile HMM method. We named these superfamilies GTS-A, $-\mathrm{B},-\mathrm{C}$ and $-\mathrm{D}$, respectively. The members of CAZy, those of Pfam and accession numbers from PDB in each superfamily, were classified into four superfamilies as summarized in Table I. Twenty-five families were classified into GTS-A, twelve families into GTS-B, seven families into GTS-C and three families into GTS-D, however thirteen families were not classified into any superfamily. Glycosyltransferases sharing the fold, GT-A or -B, were classified into GTS-A or -B respectively.

By the HMM search using the profile of each family, we found that two non-glycosyltransferase families, i.e. the nucleotidylyltransferase family and UDP- $N$-acetylglucosamine 2-epimerase (UDP-GlcNAc 2-epimerase) family are included as members of GTS-A and -B respectively (Table I).

We found a conserved acidic residue, which is involved in donor binding in SpsA from Bacillus Subtilis (4), in fifteen GT families in GTS-A (Fig. 1). However, this conserved acidic residue was not found in the other ten families in GTS-A. In these families, another conserved residue like Arg 189 of beta1,4-galactosyltransferase I ( $\beta 4 \mathrm{Gal}-\mathrm{T} 1, \mathrm{P} 08037)$ in GT-7, which is involved in binding to UDP-Gal $(5,6)$, may be involved in donor-binding. The conserved acidic residues in each family of GTS-A were also assigned the DxD motif. This motif was demonstrated to be involved in binding to a divalent cation, such as $\mathrm{Mn}^{2+}(5,6)$.

One or two acidic residues were conserved in each family of GTS-B (Fig. 2). It has been suggested that these acidic residues are required for donor-binding and/or catalytic activ-
B. プロファイル HMM 法を用いて同定された 4 種のスーパー ファミリー

我々はプロファイル HMM 法を用い、CAZy のファミリー 60 のうち47 ファミリーを4つのスーパーファミリーに分類し、 これらスーパーファミリーをそれぞれ GTS-A、B、C、D と名 づけた。表Iにそれぞれの CAZy のメンバー、Pfam およびPDB のアクセッション番号を示している。CAZy ファミリーのうち 25 ファミリーがGTS-A に、12 ファミリーがGTS-B に、7ファ ミリーがGTS-C に、3ファミリーがGTS-D に分類されたが、 13 ファミリーはスーパーファミリーへ分類されなかった。GTA フォールドもしくは GT-B フォールドを共通にもつ糖転移酵 素はそれぞれ GTS-A、GTS-B へ分類された。

それぞれのファミリーのプロファイルを用いた hmmsearch プログラムにより糖転移酵素ではない 2 つのファミリー、 nucleotidylyltransferase ファミリーと UDP- $N$-acetylglucosamine 2epimerase ファミリーがそれぞれ GTS-A と GTS-B に含まれる ということが明らかになった。

我々は、Bacillus subtilis の糖転移酵素 SpsA でドナー結合に 関わっている酸性アミノ酸残基 (4) が GTS-A の 15 ファミリー に保存されていることを見いだした(図 1)。しかし、この保存 された酸性アミノ酸は GTS-A の残りの10ファミリーでは見つ けることができなかった。これらファミリーでは、GT-7の $\beta 1,4$ ガラクトース転移酵素で UDP-Gal の結合に関与している Arg189 (5、6)のように、別の保存されたアミノ酸残基がドナー結合に関 わっていると考えられた。また、GTS-A のそれぞれのファミ リーで保存されている酸性残基を DxD モチーフとして同定し

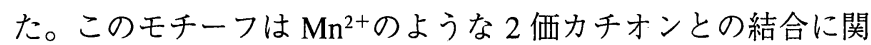
わっていると考えられている $(5 、 6)$ 。

GTS-B の各ファミリーでは、1つないし2つの酸性アミノ 酸残基が保存されていた (図 2)。これらの酸性アミノ酸残基は ドナー結合もしくは酵素活性に必要であることが示唆されてい

Table I. Classification of glycosyltransferase families.

\begin{tabular}{cllll}
\hline Superfamily & \multicolumn{1}{c}{ CAZy } & \multicolumn{1}{c}{ Pfam } & \multicolumn{1}{c}{ PDB } & similar family \\
\hline GTS-A & $2,6,7,8,12,13$, & PF00535, PF03414, PF02709, & 1h71, 1fg5, 1fgx, & nucleotidylyltransferase family \\
& $14,16,21,24,25$, & PF01501, PF03071, PF02485, & $1 \mathrm{~g} 9 \mathrm{r}, 1 \mathrm{ll0}, 1 \mathrm{f08}$, & \\
& $27,31,32,40,43$, & PF01755, PF01762, PF03360, & $1 \mathrm{fgg}$ & \\
& $44,45,46,47,48$, & PF03016, PF02364 & & \\
& $49,54,55,60$ & & & \\
GTS-B & $1,3,4,5,9,19$, & PF00201, PF00862, PF01075, & 1llr, 1f0k, 1ahp, & UDP- $N$-acetylglucosamine \\
& $20,28,30,33,35$, & PF02684, PF00982, PF04101, & 1em6, 1a8i, 1ygp & 2-epimerase family \\
& 41 & PF00343 & & \\
GTS-C & $22,39,53,50,57$, & PF02366, PF03155 & & \\
& 58,59 & & & \\
GTS-D & $11,23,37$ & PF01531 & & \\
unclassified & $10,15,17,18,26$, & PF00852, PF01793, PF03808, & & \\
& $29,34,36,38,42$, & PF00777, PF00912 & & \\
& $51,52,56$ & & & \\
\hline
\end{tabular}




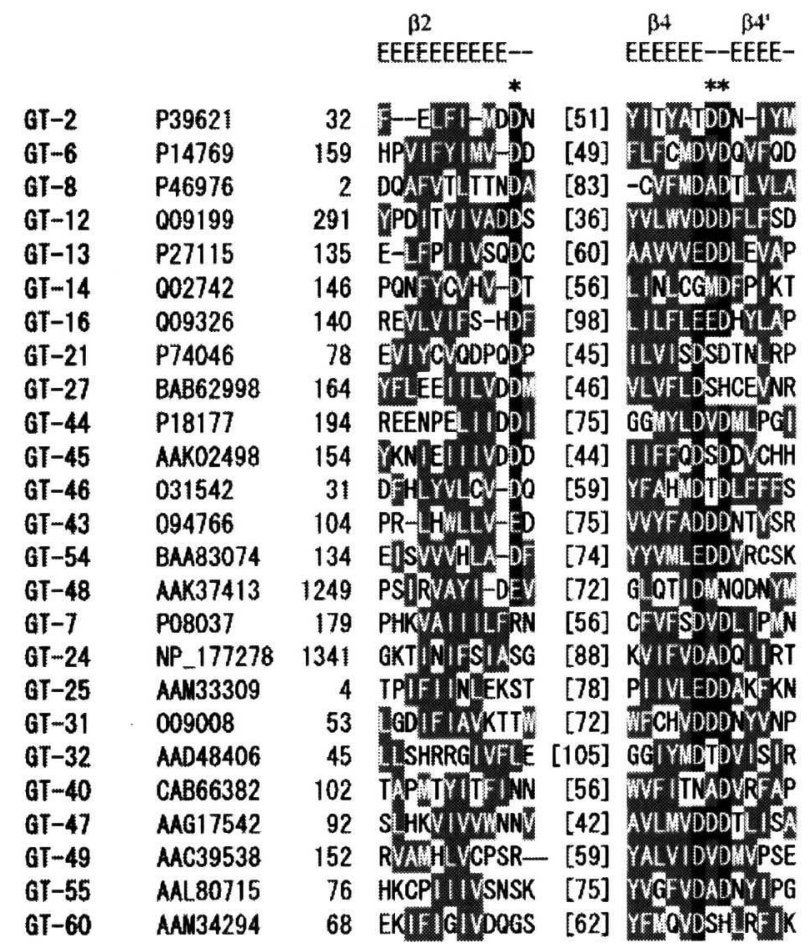

Fig. 1. Multiple sequence alignment of regions of similarity among the families in GTS-A. The CAZy family numbers and the accession numbers of each representative sequence from NCBI GenBank or SwissProt are represented on the left side of the figure. Numbers in brackets specify the number of residues in an insert between the two regions. Conserved acidic residues assigned as a motif are highlighted in red. Hydrophobic residues are highlighted in green. The secondary structure of SpsA from Bacillus Subtilis (P39621) is presented above the alignment, with E signifying $\beta$-strand residues and $\mathrm{H}$ signifying $\alpha$ helix residues. Three Asp residues involved in binding donor and divalent cations in SpsA (P39621) are indicated by asterisks.

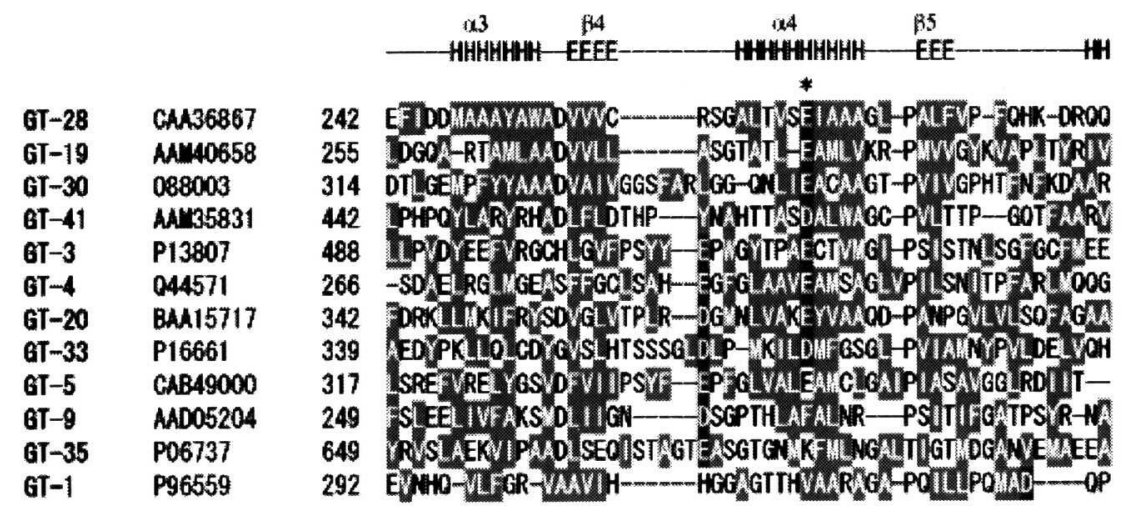

Fig. 2. Multiple sequence alignment of the region of similarity among families in GTS-B. The secondary structure of MurG (CAA36867) in GT-28 is presented above the alignment. The Glu residue involved in UDP binding in MurG (CAA36867) in GT-28 is marked by an asterisk.

ity(7). The corresponding acidic residues are not conserved in the GT-1 family. It was demonstrated that D332 of GtfB from Amycolatopsis orientalis, as highlighted in red in Fig. 2, in GT1 is important for catalytic activity by crystal structure and mutagenesis analysis (8). Thus, GT-1 may not share a mechanistic
る (7)。GT-1 ファミリーについては、上記に相当する酸性残基は 保存されていない。図 2 で赤く示されている Amycolatopsis orientalis 由来 $\mathrm{GtfB}$ の D332 は酵素活性に重要であることが結晶 構造㧍よび変異実験により示されている $(8)$ 。それゆえ、GT-1 は 他の GTS-B のメンバーと構造、機能的な類似性を示すにもかか 


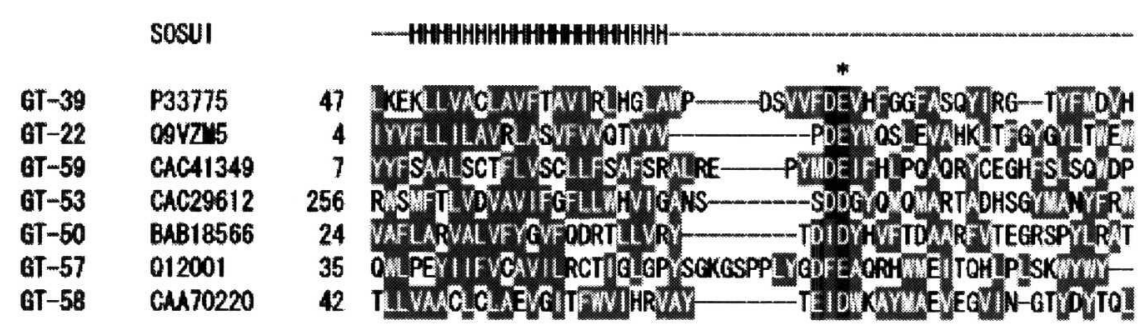

Fig. 3. Multiple sequence alignment of the region of similarity among families in GTS-C. The secondary structure of dolichyl phosphate-mannose: protein $O$-mannosyltransferase ScPmt lp (P33775) predicted by SOSUI is shown above the alignment with $\mathrm{H}$ signifying $\alpha$-helix residues. The Glu residue involved in the catalytic activity of ScPmt 1p (P33775) is marked by an asterisk.

requirement in spite of structural and functional similarity.

Glycosyltransferases which utilize dolichyl-phosphatesugars as a donor substrate are membrane proteins with multispanning transmembrane domains, and were clustered into GTSC. Recently, Oriol et al. classified the members, using a ClustalW alignment, which utilizes dolichyl-phosphate-monosaccharides as a donor substrate into three superfamilies, $\alpha 1,2-/ 1,6$ mannosyltransferases, $\alpha 1,3-/ 1,4-$ mannosyltransferases and $\alpha 1,2-11,3$ - glucosyltransferases, and hypothesized that these three superfamilies have a common evolutionary origin (9). The result for GTS-C in our classification is consistent with their results, and supported their hypothesis.

The conserved acidic residues, DE, Dx[D/E] or ExD, were found in a loop region following the first predicted helix of GTS-C (Fig. 3). It has been suggested that these acidic residues are involved in the catalytic activity of dolichyl phosphatemannose: protein O-mannosyltransferase ScPmt1p from Saccharomyces cerevisiae (10) and mannosyltransferase PIG-M from Homo sapiens (11). It is of interest that the DxD motif is conserved in both GTS-A and -C.

It was also indicated that $\alpha 1,2-/ 1,6$-fucosyltransferases are classified into GTS-D. The Arg residue conserved in a similar region among the families (Fig. 4) has been demonstrated to be involved in binding to the donor substrate, GDP-fucose (12). However, no conserved acidic residues were found in this region. Perhaps the catalytic mechanism of this superfamily is different from that of the other three superfamilies.
わらず、活性メカニズムは異なるのであろう。

Dolichyl-phoshate-sugar をドナー基質として利用する糖転移 酵素は複数膜貫通領域を持つ膜タンパクであり、GTS-Cに分類 された。最近 Oriol らは ClustalWによるアライメントを用いて dolichyl-phosphate-monosaccharide をドナー基質とするメンバー を 3 種類のスーパーファミリー $\alpha 1,2-/ 1,6-$ マンノース転移酵素、 $\alpha 1,3-/ 1,4-$ マンノース転移酵素および $\alpha 1,2-/ 1,3-$ グルコース転移酵 素に分類し、これら 3 つのスーパーファミリーが進化上共通の 起源を持つという仮説を立てた $(9)$ 。我々の分類での GTS-Cの 結果はこの仮説を支持するものである。

GTS-Cで予測された一番目の膜貫通へリックスとその後に つづくループ領域に、保存された酸性残基 DE, Dx[D/E] または ExD が見いだされた (図 3)。これら酸性アミノ酸残基はSaccharomyces cerevisiae 由来 dolichyl phosphate-mannose: protein Omannosyltransferase ScPmtl (10) とヒト由来 mannosyltransferase PIG-M (11) で酵素活性に関わっていることが示唆されている。 DxD モチーフがGTS-A と GTS-C に保存されていることは興味 深い。

$\alpha 1,2-/ 1,6-$ フコース転移酵素は GTS-D へ分類されることが示 された。このスーパーファミリーに含まれるファミリー間に(図 4)類似の領域で保存されている Arg 残基はドナー基質である GDP フコースと結合することが示唆されている(12)。しかしな がら、この領域に保存された酸性残基はみられなかった。この

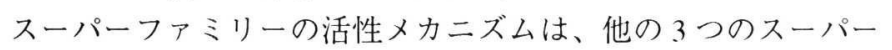
ファミリーとは異なる可能性もある。

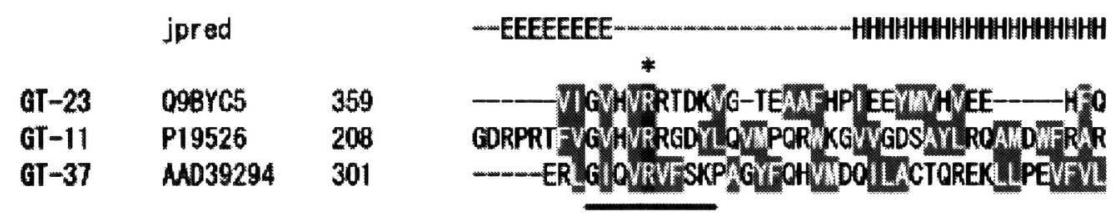

Fig. 4. Multiple sequence alignment of the region of similarity among families in GTS-D. The secondary structure of human $\alpha 1,6$-fucosyltransferase (Q9BYC5) predicted by Jpred in GT-23 is presented above the alignment. Basic, hydrophobic and acidic residues are highlighted in blue, green and red, respectively. The Arg residue involved in substrate binding in human $\alpha 1,6$-fucosyltransferase is marked by an asterisk. The corresponding Arg residues are highlighted in blue. 


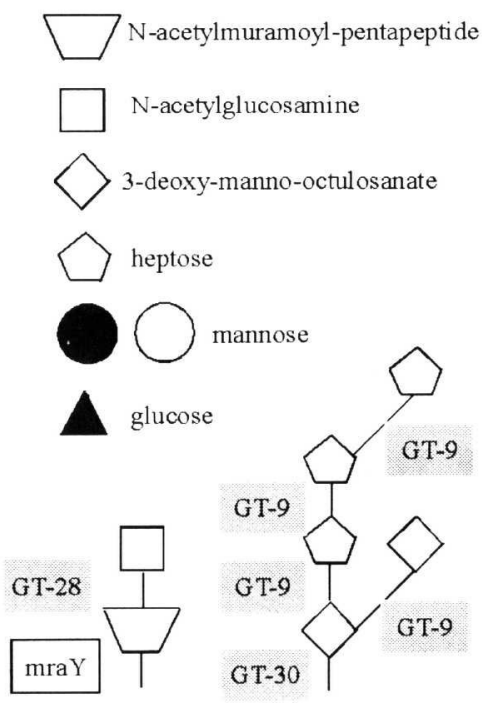

Peptide glycan

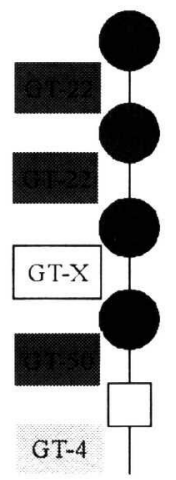

GPI-anchor

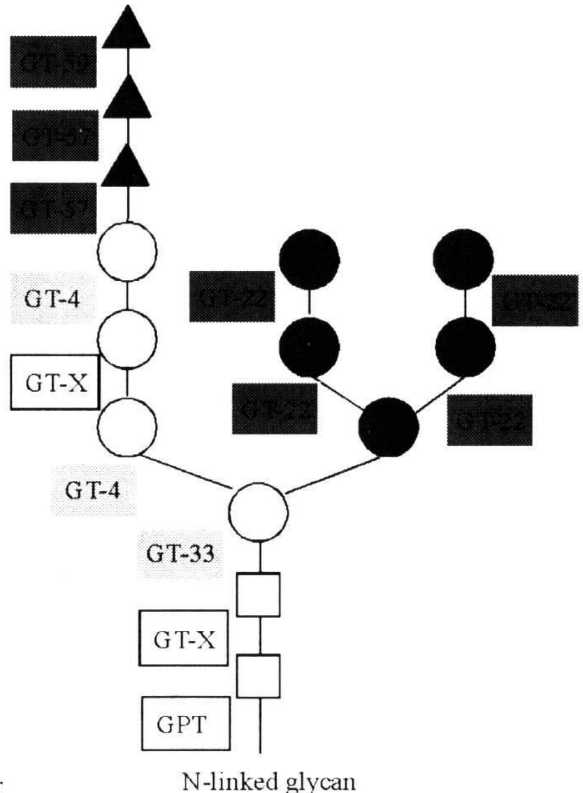

N-linked glycan

Fig. 5. Carbohydrate structures of peptide glycan, lipopolisaccharide (LPS), glycosylphosphatidylinositol anchor (GPI-anchor) and asparagines linked glycan (N-glycan), and CAZy families catalyzing the synthesis of them. Numbers in boxes indicate the family number of CAZy. The unknown family is represented by "GT-X" in a box. Each superfamily, GTS-B and -C, is indicated in yellow and red, respectively. Empty and filled symbols for sugars in GPI-anchor or $N$ glycan structures represent sugars added on the cytosolic side of the ER or lumen side of the ER, respectively. "mraY" represents phospho- $N$-acetylmuramoyl-pentapeptide-transferase and "GPT" represents GlcNAc-1-phospate transferase.

C. Sequential Participation of Each Superfamily in Glycosylation Pathways and Their Subcellular Localization

Four representative glycosylation pathways, peptide glycan of bacteria, the inner core region of bacterial lipopolysaccharide (LPS), the glycosylphosphatidylinositol anchor of eukaryotes (GPI-anchor) and the asparagine-linked glycan (N-glycan) of eukaryotes, are schematically depicted in Fig. 5. Family numbers of glycosyltransferases catalyzing each step are also shown in Fig. 5. The initiation and early steps of the synthesis of these oligosaccharides were found to be catalyzed by GTS-B members except for phospho- $\mathrm{N}$-acetylmuramoyl-pentapeptide transferase (mraY) and GlcNAc-1-phospate transferase (GPT) which are not included in the CAZy database, and not glycosyltransferases. These GTS-B members are known to act on the cytoplasmic side of the ER. In eukaryotes, the GTS-C members were found to be involved in extension of the GPIanchor and N-glycan, following the GTS-B members. Their catalytic sites are known to face the lumen side of the ER. We also identified that the synthesis of the outer core and O-specific chain of LPS in prokaryotes is catalyzed by the members of GTS-A and -B, and the synthesis of eukaryotic N-glycan in Golgi is catalyzed by members of GTS-A and -D (not shown in the figure).

We found several biologically interesting features of superfamilies, i.e. 1) the initiation of glycosylation in both prokary-
C. 糖鎖合成経路と細胞内局在における各スーパーファミリーの 分布

4 種類の代表的な糖鎖合成経路であるバクテリアのペプチド グリカン、バクテリアのリポ多糖のコア構造、真核生物のグリ コシルホスファチジルイノシトールーアンカー (GPI-anchor) およ び真核生物アスパラギン結合型糖鎖 (N-グリカン) を図 5 に示 す。また、各ステップに関与する糖転移酵素のファミリーも記 載した。Phospho- $N$-acetylmuramoyl-pentapeptide 転移醅素 (mraY) と GlcNAc-1 リン酸転移酵素 (GPT) を除き、これらオリゴ糖の 合成の開始と初期のステップは GTS-B に触媒されることが見い だされた。GTS-BのメンバーはERの細胞質側で作用すること が知られている。真核生物では、GTS-B のメンバーにつづき GTS-C のメンバーが GPI-anchor と N-グリカンの伸長に関わっ ていることが見つかった。これらの活性部位は ERのルーメン 側に面している。我々は原核生物の LPS の outer core と O-specific chain がGTS-A と GTS-Bによって、またN-グリカンのゴ ルジでの合成がGTS-A と-Dのメンバーによって行われること を同定した。

我々は、生物学的に興味深いスーパーファミリーの特徵を 見いだした。(1) 原核生物、真核生物ともに糖鎖合成の開始は糖 


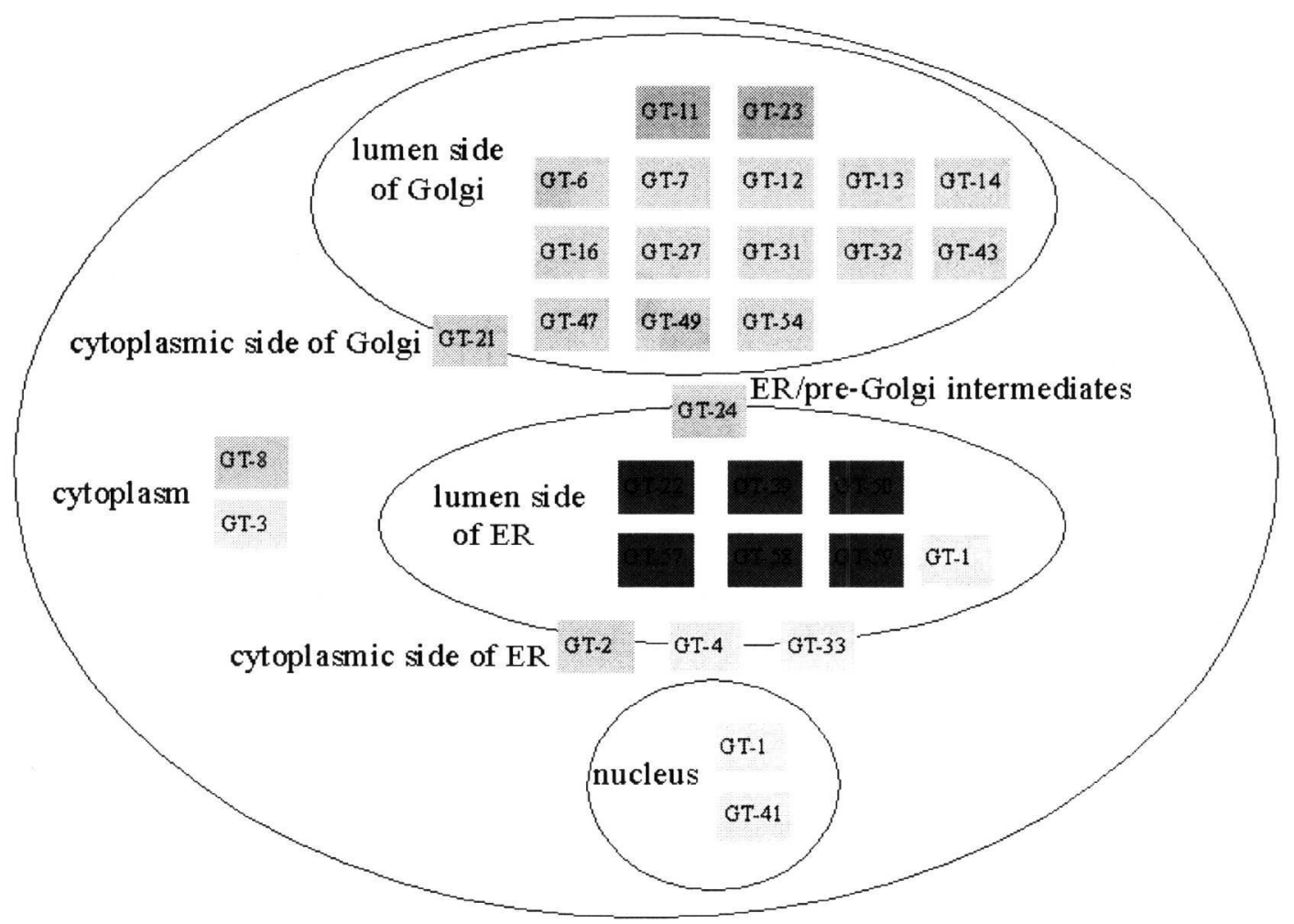

Fig. 6. Subcellular localization of each superfamily. Numbers in boxes indicate the family number of CAZy. Each superfamily, GTS-A, -B, -C and -D, is indicated in blue, yellow, red and orange, respectively.

otes and eukaryotes is catalyzed by the sugar-1-phosphate transferase family which is not included in the glycosyltransferase family, 2) the subsequent extension of the root structure of glycans is catalyzed by GTS-B in both prokaryotes and eukaryotes, and 3) in eukaryotes, the extension is further followed by GTS-C. No members of GTS-C were found in prokaryotes with one exception, the UDP-L-arabinose: arabinosyltransferase family. GTS-C increased its members only in eukaryotes, not in prokaryotes. 4) Finally, terminal glycosylation is catalyzed by a large number of GTS-A members in both eukaryotes and prokaryotes. 5) GTS-D may have evolved uniquely in eukaryotes. Thus we propose the following hypothesis. The initiation of glycosylation is catalyzed by a common ancestral suger-1 phosphate transferase that appeared before eukaryotes diverged from prokaryotes. Elongation after the initiation is catalyzed by the original GTS-B members. This indicated that GTS-B originally evolved among glycosyltransferases, and was responsible for the synthesis of the root structure. The similarity between GTS-A and the nucleotidylyltransferase family which is involved in the synthesis of nucleotide-sugars suggests that the origin of GTS-A is an enzyme catalyzing the synthesis of nucleotide-sugar. We speculate that the ancestors of GTS-A originally supplied nucleotide-sugars as donor substrates to the ancestors of nucle-
転移酵素ファミリーではなく糖-1ーリン酸転移醅素ファミリーに よって開始され、(2) 続く根元の構造の伸長は原核生物、真核生 物共に GTS-Bによって行われる。(3) 真核生物ではその後の伸 長がGTS-Cによって行われる。原核生物では 1 つの例外 (UDPL-arabinose: arabinosyltransferase ファミリー) を除き GTS-C のメ ンバーは存在しない。GTS-Cのメンバーは原核生物ではなく真 核生物のみで増加している。

(4) 最後に、末端の糖鎖合成は真核生物、原核生物共に GTSAのメンバーにより触媒される。(5) GTS-D は抢そらく真核生 物で特有に進化してきたものであろう。これらの特徵から我々 は以下の仮説を提唱した。真核生物と原核生物が分化する前の 糖鎖合成の開始は、そのころ出現した祖先型の糖-1リン酸転移 酵素により行われていた。合成開始後の伸長反応は GTS-Bによ り行われていた。これはGTS-B が元々の糖転移酵素として進化 し、根元の合成に関わってきたということを示している。GTSA と糖ヌクレオチド合成に関わる nucleotidylyltransferase ファミ リーとの類似性から GTS-A の起源は糖ヌクレオチドの合成を触 媒する酵素であることが示唆される。GTS-A の祖先は元々糖-1 リン酸転移酵素と GTS-Bに、ドナー基質である糖ヌクレオチド 
otide-1-phosphate transferase and GTS-B. Finally, GTS-A has evolved into a large family of glycosyltransferases to catalyze the synthesis of diversified carbohydrate structures such as $O$ specific chains of LPS and the terminal structure of eukaryotic $\mathrm{N}$-glycan and $\mathrm{O}$-glycan. We could not determine the origin of GTS-C. GTS-C may have developed in an evolutionary manner in eukaryotes. GTS-D, which includes only fucosyltransferases, may have a unique structure different from that of the GTS-A members, although both GTS-A and -D are localized to Golgi, and are typical type II membrane proteins.

The eukaryotic subcellular localization of each family is shown in Fig. 6. Most of the members of GTS-A and GTS-D were localized to Golgi, whereas those of GTS-B were found in the cytoplasm, nucleus and ER. All members of GTS-C were active on the lumen side of the ER. This result suggests that eukaryotic glycosyltransferases evolved from a common ancestor in each superfamily as enzymes catalyzing each subcellular component. The distinct localization of each superfamily reflects each step, in which it is involved, in the glycosylation pathway. When one finds a novel enzyme, one will be able to predict its subcellular localization and the step at which it is involved in the glycosylation pathway using this method of classification.

\section{Acknowledgments}

This work was supported by the New Energy and Industrial Technology Development Organization and performed as part of the R\&D project of the Industrial Science and Technology Frontier Program (R\&D for Establishment and Utilization of a Technical Infrastructure for Japanese Industry).
を供給する酵素であったと推察される。後に GTS-A は多くの糖 転移酵素へと進化し、LPS の $O$-specific 鎖や $N$-グリカンの末端 側の構造や O-グリカンのように多種多様な糖鎖合成を触媒する ようになった。GTS-C の起源については見つけることができな かった。おそらく GTS-C は真核生物で進化してきたのであろ う。フコース転移酵素のみを含む GTS-D は、GTS-A とは異な るユニークな構造を持つと思われるが、GTS-A と D は共にゴル ジ体に局在する典型的な 2 型膜タンパク質である。

図 6 に真核生物由来の糖転移酵素ファミリーの細胞内局在 を示す。GTS-A と GTS-D のメンバーの大部分はゴルジ体に局 在する。一方 GTS-B のメンバーは細胞質、核、ER に局在する ことが見うけられる。GTS-Cの全てのメンバーはERのルーメ ン側で活性を持つ。この結果は、真核生物の糖転移䤃素はスー パーファミリー毎に共通の祖先からそれぞれの細胞内器官で触 媒する酵素として進化してきたということを示唆している。 スーパーファミリー毎の局在の違いは、糖鎖合成経路で関わる 転移反応の違いを反映している。この分類を用いることで、新 規の酵素が見つかった際、その酵素の細胞内局在とそれが関わ る糖鎖構造合成経路のステップを予測することができるであろ う。

\section{References}

1. Laine, R. A. (1994) Glycobiology 4, 759-767

2. Campbell, J. A., Davies, G. J., Bulone, V., and Henrissat, B. (1997) Biochem. J. 326 (Pt 3), 929-939

3. Kikuchi, N., Kwon, Y. D., Gotoh, M., and Narimatsu, H. (2003) Biochem. Biophys. Res. Commun. 310, 574-579

4. Tarbouriech, N., Charnock, S. J., and Davies, G. J. (2001) J. Mol. Biol. 314, 655-661

5. Gastinel, L. N., Cambillau, C., and Bourne, Y. (1999) Embo J. 18, 3546-3557

6. Ramakrishnan, B., and Qasba, P. K. (2001) J. Mol. Biol. 310, 205-218

7. Ha, S., Walker, D., Shi, Y., and Walker, S. (2000) Protein Sci. 9, 1045-1052

8. Mulichak, A. M., Losey, H. C., Walsh, C. T., and Garavito, R. M. (2001) Structure (Camb) 9, 547-557

9. Oriol, R., Martinez-Duncker, I., Chantret, I., Mollicone, R., and Codogno, P. (2002) Mol. Biol. Evol. 19, 1451-1463

10. Girrbach, V., Zeller, T., Priesmeier, M., and Strahl-Bolsinger, S. (2000) J. Biol. Chem. 275, 19288-19296

11. Maeda, Y., Watanabe, R., Harris, C. L., Hong, Y., Ohishi, K., Kinoshita, K., and Kinoshita, T. (2001) Embo J. 20, 250-261

12. Yamaguchi, Y., Ikeda, Y., Takahashi, T., Ihara, H., Tanaka, T., Sasho, C., Uozumi, N., Yanagidani, S., Inoue, S., Fujii, J., and Taniguchi, N. (2000) Glycobiology 10, 637-643 


\section{Profile of the Author}

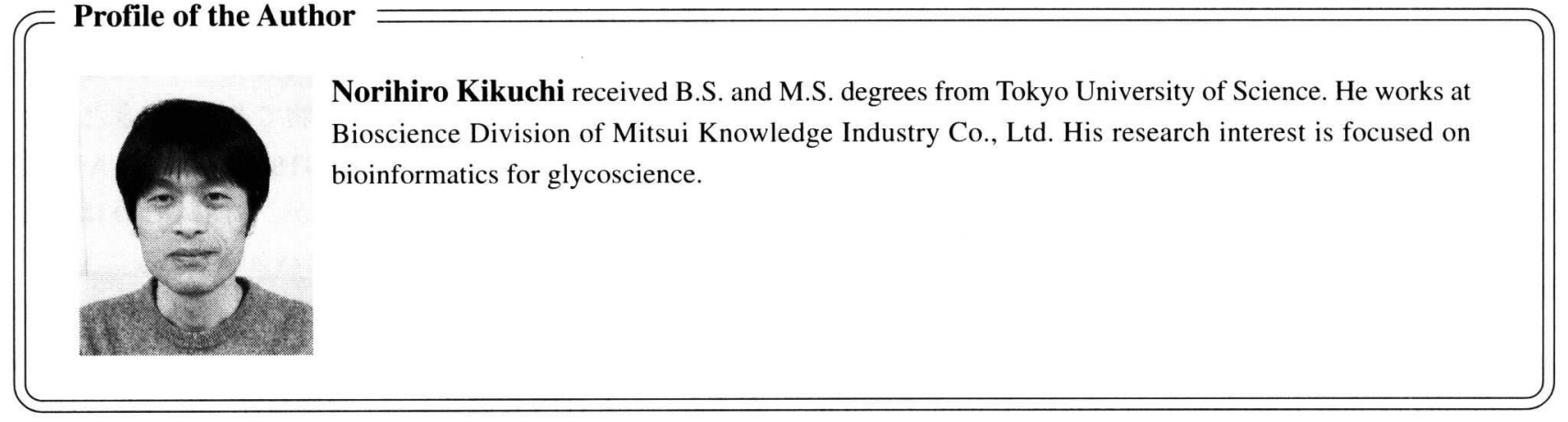

